\title{
TRAFFIC NOISE AS A FACTOR INFLUENCING APARTMENT PRICES IN LARGE CITIES
}

\author{
Agnieszka Szczepańska, PhD \\ Faculty of Geodesy and Land Management \\ University of Warmia and Mazury in Olsztyn \\ e-mail:aszczep@uwm.edu.pl
}

\author{
Adam Senetra, PhD \\ Faculty of Geodesy and Land Management \\ University of Warmia and Mazury in Olsztyn \\ e-mail:adam.senetra@uwm.edu.pl \\ Monika Wasilewicz, M. Sc. \\ Faculty of Geodesy and Land Management \\ University of Warmia and Mazury in Olsztyn \\ e-mail:monika.wasilewicz@uwm.edu.pl
}

\begin{abstract}
Environmental factors are among the key determinants of real estate prices. They include landscape attractiveness, land relief, exposure to sunlight and proximity to natural features. In large urban centers, traffic noise emissions significantly affect decision-making on the real estate market. Weakly developed road networks and the absence of ring roads that shift road traffic outside residential districts are a widespread problem in the cities of Central-Eastern Europe. The prevention of traffic noise pollution, one of the key environmental problems in Europe, is an important goal of European Union policy. This paper analyzes the correlations between apartment prices and traffic noise levels in Olsztyn, the capital city of the Warminsko-Mazurskie Voivodeship (province) in north-eastern Poland. A linear correlation analysis was performed, and the distribution of unit prices of apartments was mapped by ordinary kriging.
\end{abstract}

Key words: soundscape, noise level, traffic noise, real estate value.

JEL Classification: C21, Q53.

Citation: Szczepańska A., Senetra A., Wasilewicz A., 2014, Traffic noise as a factor influencing apartment prices in large cities, Real Estate Management and Valuation, vol. 22, no. 3, s. 37-44.

DOI: $10.2478 /$ remav-2014-0025

\section{Introduction}

Soundscape is a term that describes the acoustic environment. The concept was introduced in 1977 (RAIMBAULT, DUBOIS 2005). Soundscape evaluations rely on analyses of various sound qualities. Road traffic noise is recognized as one of the greatest annoyances. It poses a particular problem in highly urbanized areas (YANG, KANG 2005). Cities produce different types of sounds that make up the soundscape, including background noise, mechanical equipment, human activity, noises of nature, human presence, speech and communication (GARRIOCH 2003; LEBIEDOWSKA 2005).

The prevention and control of traffic noise through the achievement of a high level of health and environmental protection is one of the objectives of European Union policy. The relevant goals have been outlined in Directive 2002/49/EC of the European Parliament and of the Council of 25 June 2002 
relating to the assessment and management of environmental noise. The Directive places Member States under obligation to monitor the observance of allowable noise limits. Acoustic maps are the main diagnostic tool in this process.

Annoyance caused by excessive noise levels is reflected in the prices of real estate. Neighborhood quality is an important factor that influences buyers' decision to purchase property. The objective of this study was to evaluate the correlations between traffic noise levels and prices on the local apartment market in Olsztyn, the capital city of the Warminsko-Mazurskie Voivodeship in northeastern Poland

\section{Traffic noise and property prices}

Road traffic noise is caused by two main factors: tire-pavement interactions and noise generated by a vehicle's engine and exhaust system. Noise levels higher than $55 \mathrm{~dB}$ are a source of discomfort for most people, and the allowable noise limit is set at $65 \mathrm{~dB}$ (Directive 2002/49/EC of the European Parliament.... 2002).

Urban traffic noise contributes to health problems, such as sleep disturbance, loss of productivity and physiological stress, but it also has adverse economic consequences by driving down the prices of real estate (PAPI, HALLEMAN 2004). The economic consequences of noise pollution which are discussed in this paper are directly linked with social aspects. This problem is most visible in the segment of housing and recreational real estate where noise pollution considerably influences the value of property. In those areas, rest and recreation are very important functions, therefore noise is a highly undesirable factor. In literature, the impact of noise on real estate prices is generally investigated in the housing sector (BENOIT, LANOIE 2007; BLANCO, FLINDELL 2011; KARANIKOLAS et al. 2011; KIM et al. 2007 , NELSON 2008; WILHELMSSON 2000). Most studies analyze statistical correlations between changes in noise intensity and changes in real estate value. The Noise Sensitivity Depreciation Index (NSDI) is one of the most popular indicators for describing the impact of road traffic noise on real estate prices. NSDI determines the percentage change in property prices per $\mathrm{dB}$ increase in noise levels (BLANCO, FLINDELL 2011). In studies of road traffic noise, NSDI was determined in the range of $0.08 \%$ to $2.22 \%$. Research results clearly indicate that noise pollution considerably affects property prices.

\section{Research object}

The study was carried out in Olsztyn, the capital city of the Warminsko-Mazurskie voivodeship in north-eastern Poland. Olsztyn has a population of 200,000. Its suburban region has an estimated population of 120,000, and it stretches within a $20 \mathrm{~km}$ radius from the city's administrative boundaries. The majority of suburban residents commute to Olsztyn on a daily basis. Olsztyn has population density of 1998 people per $1 \mathrm{~km}^{2}$.

Olsztyn is exposed to heavy through traffic on account of its location and infrastructural deficiencies. The main factors that contribute to high levels of traffic in transit include Olsztyn's significance as a regional center of economic activity, an absence of a ring road system, the region's proximity to Russian and Lithuanian borders and the Baltic Sea, and the presence of key transit routes connecting Eastern and Northern Europe (Belarus, Ukraine, Latvia, Estonia and Finland) with Western Europe (Germany, France, Austria). Olsztyn has $242 \mathrm{~km}$ of paved roads per $100 \mathrm{~km}^{2}$. It is one of the main transport hubs leading to destinations in eastern and north-eastern parts of Europe. The above factors make Olsztyn an ideal location for analyzing the impact of traffic noise on local property prices.

A housing estate comprising apartment buildings in central Olsztyn was analyzed. The estate is exposed to high levels of road traffic which is generated mainly by goods vehicles traveling between Central Europe and northern and north-eastern parts of the European continent. Detailed analyses were carried out in a section of the Pojezierze-Kormoran housing estate in the Centrum district where noise pollution levels are particularly high (Fig. 3 and Fig. 4).

The evaluated real estate features apartments in multifamily residential buildings. To consolidate experimental samples and eliminate other price-shaping factors, the analyzed data was sorted to produce transactions relating to apartments with the same legal status, apartments in buildings erected based on the same construction technology and in similar condition, apartments with similar area, situated in distinct housing estates. The main differentiating factor was location relative to a road. 


\section{Acoustic map}

Upon its accession to the European Union, Poland became subject to the provisions of the Environmental Noise Directive 2002/49/EC of 25 June 2002. Point 10 of the Resolution imposes strategic noise mapping in certain areas of interest for capturing the data needed to provide a representation of noise levels perceived within that area. Pursuant to the provisions of the Directive and the Polish Environmental Protection Law of 27 April 2001 (Journal of Laws of 2008, No. 25, item $150)$, acoustic maps have to be developed for urban areas with population higher than 100,000 . The following indicators are used to describe levels of environmental noise in an acoustic map (Regulation of the Minister of the Environment changing regulation ....2012):

1) $\mathrm{L}_{\mathrm{N}}$ - long-term indicator of average night-time noise, determined on every night of the year,

2) LDWN - long-term indicator of average noise level A, expressed in decibels, determined on every day of the year in view of the time of day (1):

$$
L_{D W N}=10 \lg \left[\frac{12}{24} 10^{0.1 L_{D}}+\frac{4}{24} 10^{0.1\left(L_{W}+5\right)}+\frac{8}{24} 10^{0.1\left(L_{N}+10\right)}\right]
$$

where:

$\mathrm{L}_{\mathrm{D}} \quad$ - long-term indicator of average noise level $\mathrm{A}$, expressed in decibels $(\mathrm{dB})$, determined during the day throughout the year (from 6 a.m. to 6 p.m.),

$\mathrm{L}_{W} \quad$ - long-term indicator of average noise level $\mathrm{A}$, expressed in decibels $(\mathrm{dB})$, determined during the evening throughout the year (from 6 p.m. to 10 p.m.),

$\mathrm{L}_{\mathrm{N}} \quad$ - long-term indicator of average noise level $\mathrm{A}$, expressed in decibels $(\mathrm{dB})$, determined during the night throughout the year (from 10 p.m. to 6 a.m.).

The maximum values of $\mathrm{L}_{\mathrm{DWN}}$ (Regulation of the Minister of the Environment changing regulation ....2012) are set at $68 \mathrm{~dB}$ for road traffic noise in housing estates comprising apartment buildings and $70 \mathrm{~dB}$ in downtown areas of cities with a population higher than 100,000.

The long-term indicator of average noise level $\left(\mathrm{L}_{\mathrm{DWN}}\right)$ for apartments was determined $4 \mathrm{~m}$ above ground along building facades most exposed to road traffic noise in the following intervals of $\mathrm{dB}$ values: $45-50,50-55,55-60,60-65,65-70,70-75,>75$.

\section{Methodology, results and discussion}

The study was carried out on the assumption that the quality of the acoustic environment in the vicinity of a residential building (noise levels determined by the building's location relative to roads) influences prospective buyers' decision to purchase property. Data relating to 215 apartment transactions in the Centrum district, including 148 transactions concluded in a selected section of the Pojezierze-Kormoran housing estate, was analyzed. Apartment prices were converted to euros according to the average EUR/PLN exchange rate announced by the National Bank of Poland as at 31 December 2013 (EUR 1 = PLN 4.1472). Data relating to apartment transactions conducted between January 2011 and December 2012 was analyzed in the study. In that period, the time trend in prices reached $0 \%$.

The study was carried out in four principal stages:

1) Traffic noise levels were determined based on the acoustic map that shows noise intensity intervals. Upper limit values in the intervals were assigned to transactions. The data shown in Figure 3 indicates that the main roads generate very high levels of noise. In selected buildings, noise levels were as high as $65-70 \mathrm{~dB}$.

2) The distribution of unit prices of apartments was mapped relative to noise levels. Price distributions for the entire Centrum district are shown in Figure 1 and for the analyzed section of the Pojezierze-Kormoran housing estate - in Figure 2. An increase in noise levels by $1 \mathrm{~dB}$ was accompanied by a drop in apartment prices by EUR $7.41 / \mathrm{m}^{2}$ in the entire Centrum district and by EUR $8.17 / \mathrm{m}^{2}$ in the analyzed section of the estate. NSDI was determined at $0.74 \%$ in the Centrum district and at $0.83 \%$ in the analyzed section of the Pojezierze-Kormoran housing estate. The above NSDI values are consistent with those reported in other studies (see Section 2 ), and indicate that apartment prices are affected by traffic noise levels.

3) Linear correlations between unit prices of apartments and noise levels were analyzed. A statistical correlation between a dependent variable (unit prices of an apartment) and an 
independent variable (noise level) was determined by Pearson's linear correlation analysis. Pearson's correlation coefficients were determined at -0.41 for the entire Centrum district (Table 1) and -0.47 for the Pojezierze-Kormoran estate (Table 2). The reported results point to a correlation between the investigated attributes. A negative value of the correlation coefficient indicates that unit prices of apartments decrease with an increase in noise levels.

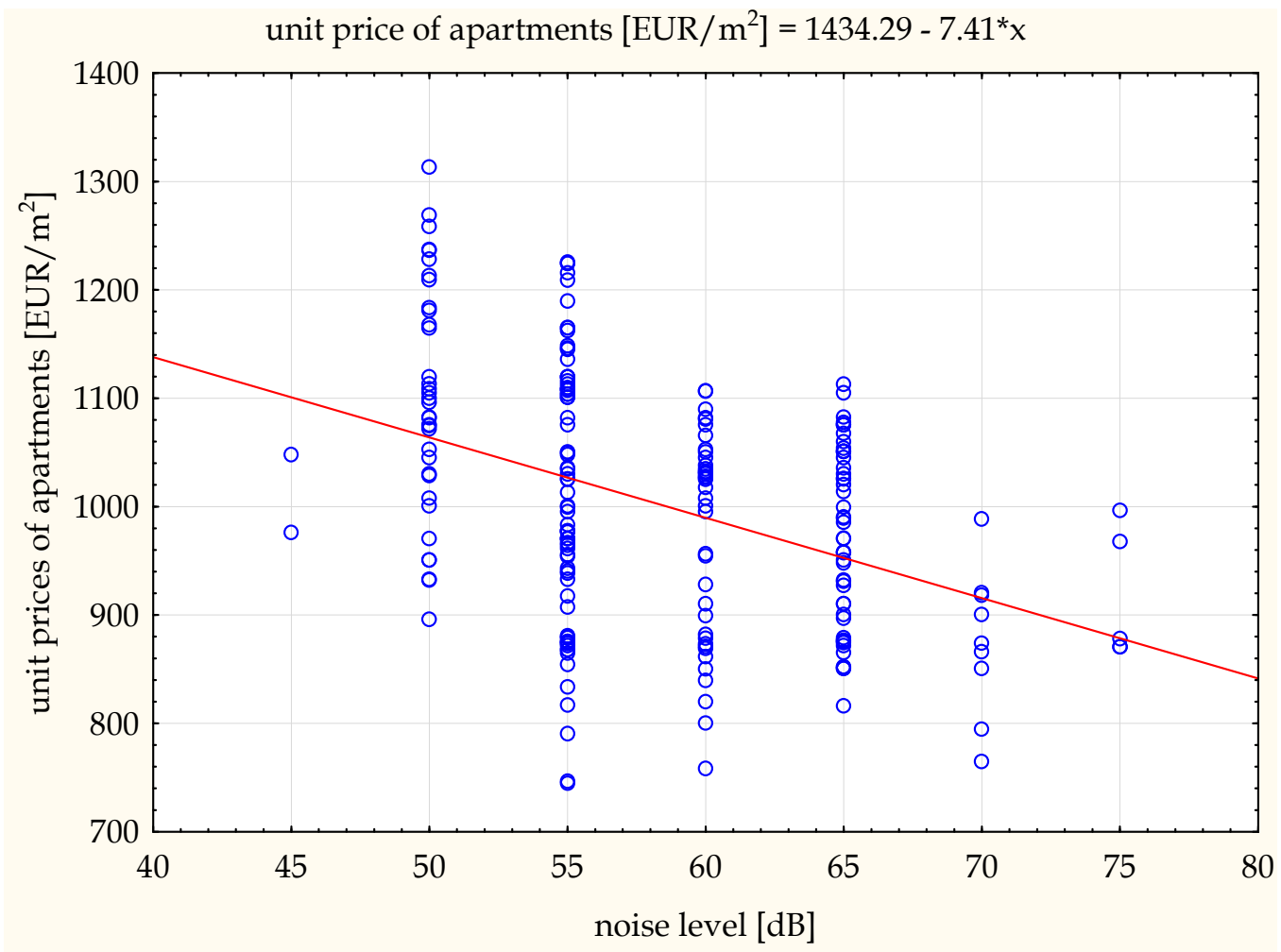

Fig. 1. Distribution of unit prices of apartments relative to noise levels $L_{D W N}$

- Centrum district. Source: own study.

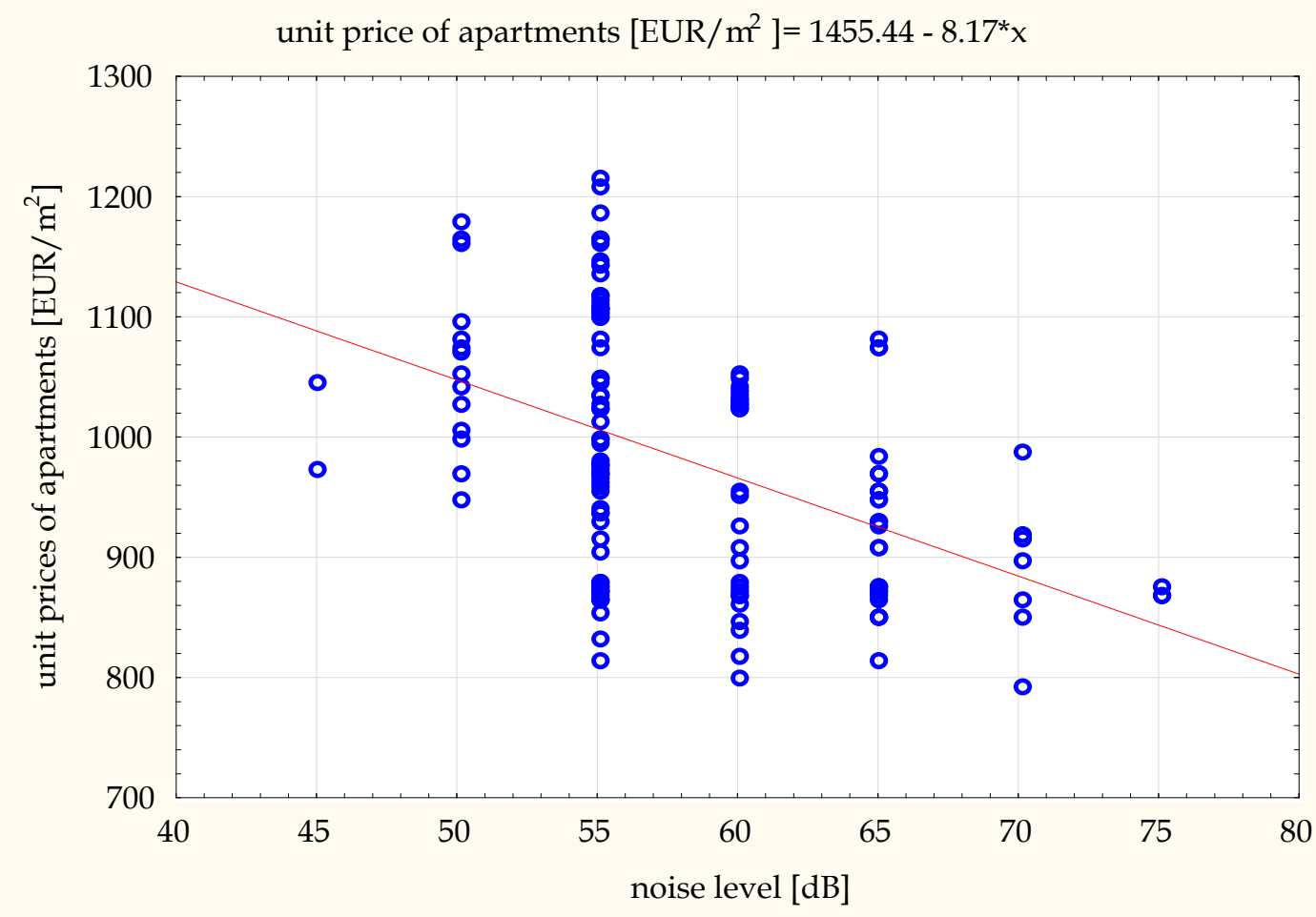

Fig. 2. Distribution of unit prices of apartments relative to noise levels $L_{D W N}$ - section of the Pojezierze-Kormoran housing estate. Source: own study. 
Linear correlation between unit prices of apartments

Table 1 and noise levels - Centrum district

\begin{tabular}{|c|c|c|c|c|}
\hline \multirow{2}{*}{ Variable } & \multicolumn{4}{|c|}{$\begin{array}{l}\text { Correlations (unit prices of apartments }\left[\mathrm{EUR} / \mathrm{m}^{2}\right] \\
\qquad- \text { noise level }[\mathrm{dB}] \text { ); } \mathrm{N}=215 \\
\text { Correlation coefficients are significant at } \mathrm{p}<.05000\end{array}$} \\
\hline & Average & SD & $\begin{array}{l}\text { unit price } \\
{\left[\mathrm{EUR} / \mathrm{m}^{2}\right]}\end{array}$ & $\begin{array}{c}\text { noise level } \\
\text { [dB] }\end{array}$ \\
\hline unit price $\left[E U R / m^{2}\right]$ & 1001.61 & 114.79 & 1.00 & -0.41 \\
\hline noise level [dB] & 58.40 & 6.33 & -0.41 & 1.00 \\
\hline
\end{tabular}

Source: own study.

Linear correlation between unit prices of apartments and noise levels

Table 2 - section of the Pojezierze-Kormoran housing estate

\begin{tabular}{|c|c|c|c|c|}
\hline \multirow{2}{*}{ Variable } & \multicolumn{4}{|c|}{$\begin{array}{l}\text { Correlations (unit prices of apartments }\left[\mathrm{EUR} / \mathrm{m}^{2}\right] \\
\qquad- \text { noise level }[\mathrm{dB}] \text { ); } \mathrm{N}=148 \\
\text { Correlation coefficients are significant at } \mathrm{p}<.05000\end{array}$} \\
\hline & Average & SD & $\begin{array}{l}\text { unit price } \\
{\left[\mathrm{EUR} / \mathrm{m}^{2}\right]}\end{array}$ & $\begin{array}{c}\text { noise level } \\
{[\mathrm{dB}]}\end{array}$ \\
\hline unit price $\left[\mathrm{EUR} / \mathrm{m}^{2}\right]$ & 980.10 & 102.17 & 1.00 & -0.47 \\
\hline noise level [dB] & 58.28 & 5.94 & -0.47 & 1.00 \\
\hline
\end{tabular}

Source: own study.

4) The distribution of unit prices of apartments was mapped by ordinary kriging to graphically illustrate the distribution of apartment prices versus road networks. Isoline interpolation tools available in ArcGIS 10 software were used. Kriging is a geostatistical estimation method which accurately estimates the values of the analyzed variables. Kriging estimates are assumed to be a weighted, linear combination of random regionalized variables. The following value is a kriging estimator (2) represented by a random function $\mathrm{Z}\left(\mathrm{s}_{\mathrm{i}}\right)$ :

$$
Z^{*}\left(s_{0}\right)=\sum_{i=1}^{n} w_{i} Z\left(s_{i}\right)
$$

where: $w_{i}$ are kriging weights.

The weights are calculated on the assumption of minimum variance is estimation errors. In ordinary kriging, the sum of weights has to be equal to one (BOURASSA et al. 2003).

The map in Figure 4 presents the section of the housing estate which is most exposed to traffic noise, as demonstrated by distribution diagrams (Fig. 1 and Fig. 2) and linear correlations (Tables 1 and 2).

In the analyzed section of the Pojezierze-Kormoran estate, the lowest prices were reported for apartments exposed to high levels of noise (Fig. 4) and situated along a national transit road and the main municipal transport corridors. Higher prices were quoted for apartments situated inside the estate where noise levels are considerably lower. In the studied section of the Pojezierze-Kormoran estate, the maximum price (EUR 1216/ $\mathrm{m}^{2}$ ) was lower than the maximum price reported for the entire Centrum district (EUR 1313/ $\mathrm{m}^{2}$ ). The above indicates that high levels of noise along the main transport routes affect buyers' decisions to purchase property. This observation is also validated by average apartment prices which were determined at EUR 1002/ $\mathrm{m}^{2}$ in the Centrum district and EUR $980 / \mathrm{m}^{2}$ in the analyzed section of the Pojezierze-Kormoran estate. 


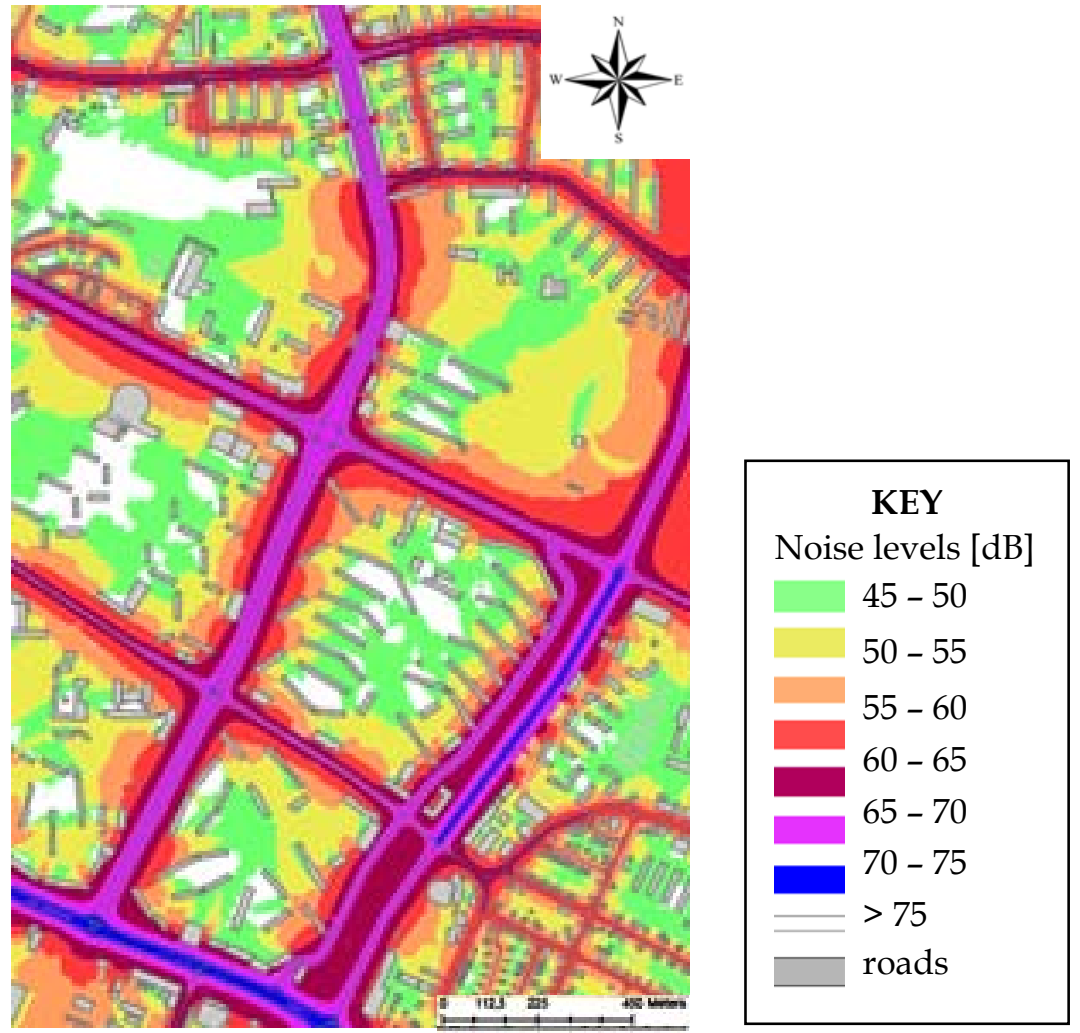

Fig. 3. Acoustic map of Olsztyn - section of the Pojezierze-Kormoran housing estate. Source: own study.

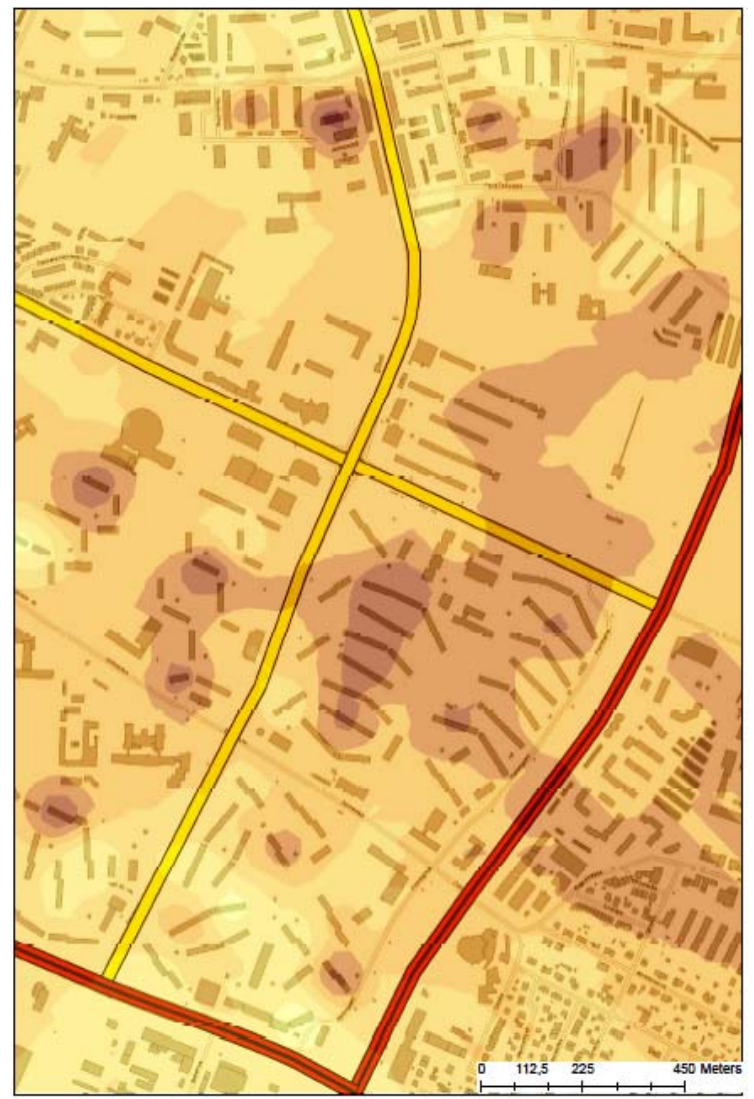

KEY

Unit prices of apartments [EUR/ $\left.\mathrm{m}^{2}\right]$

$795-877$

$877-948$

$948-1009$

$1009-1061$

$1061-1122$

$1122-1193$

$>1193$

transit roads

municipal transit corridor

other roads

buildings

Fig. 4. Distribution of unit apartment prices in the analyzed section of the Pojezierze-Kormoran housing estate. Source: own study. 


\section{Conclusions}

Acoustic maps developed for large cities in the European Union are an abundant source of analytical data concerning the spatial distribution of traffic noise sources. They are used to identify the correlations between road traffic noise and prices on the local real estate market. The results of this study presented in graphic and analytical form indicate that noise pollution is an important determinant of real estate prices.

Traffic noise control and prevention is one of the most significant problems in highly urbanized areas. Acoustic maps play a very important role in the prevention of the adverse consequences of traffic noise. An overview of the applicable legal acts suggests that traffic noise control is a difficult challenge. In 2012, the legal regulation of 2007 (Regulation of the Minister of the Environment on permissible... 2007) was amended by significantly increasing permissible noise levels for apartment buildings from $60 \mathrm{~dB}$ to $68 \mathrm{~dB}$. In downtown areas of cities with population greater than 100,000, noise limits were raised from $65 \mathrm{~dB}$ to $70 \mathrm{~dB}$. The introduction of higher noise limits should not be the principal measure in national policies aiming to combat the harmful effects of noise.

Isoline maps developed with the use of GIS tools are a rich source of information about the spatial distribution of environmental factors. Isoline maps help urban planners to minimize the annoyances experienced by urban residents. The identification of phenomena illustrated by isoline maps supports the initiation of measures that prevent real estate devaluation and protect local residents by introducing restrictions on the construction and expansion of housing estates in areas most exposed to traffic noise

\section{References}

BenOIT J., LANOIE P., 2007, The Effect of Noise Barriers on the Market Value of Adjacent Residential Properties, International Real Estate Review, 10(2), pp. 113-130.

BlanCO J.C., Flindell I., 2011, Property prices in urban areas affected by road traffic noise, Applied Acoustics, 72, pp. 133-141.

BOURASSA S.C., CANTONI E., HoEsLi M., 2007, Spatial Dependence, Housing Submarkets, and House Price Prediction, Journal of Real Estate Finance and Economics, 35, pp. 143-160.

Directive 2002/49/EC of the European Parliament and of the Council of 25 June 2002 relating to the assessment and management of environmental noise, Brussels, 2002.

GARRIOCH D., 2003, Sounds of the city: the soundscape of early modern European towns, Urban History 30(1), pp. 5-25.

KARANIKOlas N., VAGIONA D., XIFILIDOU A., 2011, Real Estate Values and Environment: a Case Study on the Effect of the Environment on Residential Real Estate Values, International Journal of Academic Research, 3(1): 861-868.

KIM K.S., PARK S.J., KWEON Y.J., 2007, Highway traffic noise effects on land price in an urban area, Transportation Research Part D: Transport and Environment, 12(4), pp. 275-280.

Lebiedowska B., 2005, Acoustic background and transport noise in urbanised areas: A note on the relative classification of the city soundscape, Transportation Research, Part D 10, pp. 341-345.

Nelson J.P, 2008, Hedonic Property Value Studies of Transportation. Noise Aircraft and Road Traffic, In: BARANZINI A. (ed.) Hedonic Methods in Housing Market Economics, Springer, pp.57-82.

PaPI J., Halleman B., 2004, Road Traffic Noise The Road Sector's Perspective. The European Union Road Federation.

Prawo ochrony środowiska z 27 kwietnia 2001r., Dziennik Ustaw z 2008, nr 25, pozycja 150 (Environmental Protection Law of 27 April 2001, Journal of Laws of 2008, No. 25, item 150).

RAIMBAUlt M., Dubois D., 2005, Urban soundscapes: experiences and knowledge, Cities, 22(5), pp. 339-350.

Rozporządzenie Ministra Środowiska z dnia 1 października 2012 r. zmieniające rozporzadzenie w sprawie dopuszczalnych poziomów hałasu w środowisku, Dziennik Ustaw z 2012r., nr 0, pozycja 1109 (Regulation of the Minister of the Environment changing regulation on permissible sound levels in the environment of 1 October 2012, Journal of Laws of 2012, No. 0, item 1109).

Rozporządzenie Ministra Środowiska z dnia 14 czerwca 2007 r. w sprawie dopuszczalnych poziomów hałasu w środowisku, Dziennik Ustaw z 2007r., nr 120, pozycja 826 (Regulation of the Minister of the Environment on permissible sound levels in the environment of 14 June 2007, Journal of Laws of 2007, No. 120, item 826). 
WilHelmsson M., 2000, The Impact of Traf.c Noise on the Values of Single-family Houses, Journal of Environmental Planning and Management, 43(6), pp. 799-815.

YANG W., KANG J., 2005, Soundscape and Sound Preferences in Urban Squares: A Case Study in Sheffield, Journal of Urban Design, 10(1), pp. 61-80.

http://213.184.21.79/geoportal/dotnetviewerolsztyn/ajaxviewerolsztyn.aspx, 15.08.2013. 